\section{AN INCIDENT IN THE CHOLERA EPIDEMIC AT ALTONA.}

THE third contribution by Dr. Koch last year to the subject of cholera appears in the Zeitschrift fïr Hygiene, vol. xv. part I. It covers no less than seventy-six pages, and is entitled "Die Cholera in Deutschland während des Winters 1892 bis 1893." As the title implies, it is an elaborate essay giving a most lucid and remarkably interesting exposition of the rise and course pursuea by the several epidemics of cholera which visited Hamburg, Altona, and Nietleben near Halle, respectively. Several figures serve to illustrate the descriptions of sites, buildings, \&c., referred to in the text.

From a bacteriological point of view, perhaps the most interesting part of the paper is that which relates to the disease in Altona, and in which an account is given of the successful elucidation of a remarkable outburst of cholera which occurred in a restricted area of that town, and which in many respects recalls the incidents of the now classical cholera explosion which took place in 1854 in connection with the Broad-street pump in London.

In a district of Altona, rejoicing in the suggestive name of "der lange Jammer," and inhabited by about 270 persons, cholera made its appearance on january $2 \mathrm{I}$, 1893 , and in a week nine cases had occurred, of which seven ended fatally. Strange to say, in the neighbourhood and, indeed, for some distance around this centre, no other cases of cholera were recorded at all, thus pointing very clearly to some local cause as responsible for the outbreak. A searching investigation was at once instituted, resulting in the discovery that the infected houses were not connected with the Altona watersupply, but dependent for their water upon a well in their midst. The ordinary town water-supply was in fact regarded as an article of luxury and an extravagance which the humble inhabitants of "der lange Jammer" were too poor to indulge in. In May, I892, a systematic investigation had, it appears, been made of all the wells in Altona, and ninety-two out of $366 \mathrm{had}$ been condemned as unfit for use. This particular well was, however, amongst those which had been passed, as its construction appeared to be satisfactory, and its surroundings sufficiently protected to remove all fear of contamination. During the severe frost, however, there can be no doubt that surface water, unable to get away by the usual channels, gained access to the well, for when the courts of the surrounding houses were washed down with strong carbolic it was noticed that the well-water acquired a smell of this material. Thus the possibility of its contamination with choleraic matters was established, and on January 26 the well was closed. After this date only four more cases of cholera occurred, the last one recorded being on February 1 , and all of these might have been contracted prior to the closing of the well, and are therefore still attributable to the use of this water.

The bacteriological examination of the water was taken in hand on January 31 , and on this day large numbers of cholera bacilli were revealed by the usual special methods employed. A sample of the water collected on January 31 was preserved for further investigation, and was kept in a room having a tenıperature of $3-5^{3} \mathrm{C}$.: in this sample cholera bacilli were found on the 2 nd, 3 rd, and 17 th February respectively, showing that under the particular circumstances the bacilli were able to maintain their vitality for eighteen days in the water; on the other hand, in samples of water collected later directly from the well itself no cholera bacteria could be detected. It is to be presumed, therefore, that as no further cases of cholera occurred in the adjacent houses after February I, no fresh bacilli found their way into the well, and those cholera bacilli which were proved to be present on January $3 \mathrm{I}$, must have either become altogether extinct or have been so much reduced in number as to defy detection.

The incident is instructive, if only in demonstrating the folly of presuming that a well with flagrantly unsanitary environment may be regarded as safe for drinking purposes, just because its past history happens to be untarnished by any observed connection with an outbreak of zymotic disease. But another point which I consider is very clearly brought out by the case in question, is the uncertainty which attaches to the actual discovery of the cholera or, indeed, of other pathogenic bacteria in water, even under such peculiarly favourable conditions as were present in the case of the Altona well. Had the examination of this water been delayed only for a few days, the search for cholera bacilli would have been absolutely fruitless, and the direct bacteriological evidence entirely wanting. Chance, in this particular instance, decided otherwise, and a very satisfactory confirmation of a most probable hypothesis was obtained.

Nevertheless, it is very apparent that however important bacteriological evidence may be in determining the hygienic value of water purification processes, and as I have so often pointed out, it is in this matter the only competent referee; on the other hand, in the matter of the actual detection of disease organisms in any given water, its usefulness is of a much more restricted character.

There is undoubtedly a tendency at the present time to regard the detection of pathogenic bacteria as the most important object of bacteriological water examination. It is, however, surely a matter of far greater moment to anticipate and be forearmed against evil by ascertaining whether the principal conditions, such as purity of source, efficiency of subsidence, filtration, \&c. attaching to a given water-supply are such as to reduce to a minimum the danger of its disseminating zymotic disease, than to wait for the actual discovery of pathogenic bacteria, and only then to be led to see the necessity of, as it were, locking the stable-door after the horse has been stolen!

The failure to discover the typhoid bacillus in the Worthing water-supply is another instance in point, and in the majority of cases the task of tracing the connection between an outbreak of disease and an infected water-supply must obviously still be performed without the direct support of the bacteriological detection of the zymotic poison.

PERCY FRANKLAND.

\section{NOTES.}

Тнв foundation of the Bakerian Lecture, to be delivered to-day at the Royal Society by Prof. Thorpe, F.R.S., and Mr. J. W. Rodger, although not so ancient as that of the Croonian, is yet of respectable antiquity. Established during the presidency of Sir John Pringle, the predecessor of Sir Joseph Banks, it has its origin in the bequest, in. 1774, hy Henry Baker, antiquary, naturalist, and Fellow of the Society, of the sum of one hundred pounds, the interest of which is directed to be applied for an oration, or discourse, to be spoken or read yearly by a Fellow on some subject in natural history or experimental philosophy. The forfeiture of the bequest is contingent on the lecture failing to be delivered in any one year. The founder of this lecture was himself a man of considerable parts, and, besides being the author of numerous memoirs in the Philosophical Transactions published two treatises on the microscope, and some poetical works. He was elected into the Royal Society in 1740 , and in 1744 was awarded the Copley medal. He married the youngest daughter of Daniel De Foe. The first lecture under the bequest was given in 1775 by $\mathrm{Mr}$. Peter Woulfe, the subject being "Experiments made in order to ascertain the nature of some

No. I 269 . VOL. 49] 